\title{
INFORMACIÓN SOBRE CRITERIOS DE CALIDAD DE LA REVISTA DE PSICOPATOLOGÍA Y PSICOLOGÍA CLÍNICA
}

doi: 10.5944/rppc.vol.21.num.3.2016.17815

Indicadores de impacto de la revista:

\section{Scopus}

Scimago Journal Rank (2015):

$0.42(\mathrm{Q} 2)$

Cites per document (2015):

\section{Google Académico}

Índice $\mathrm{h}$ (total):

Índice h (desde 2011):

Índice 10 (total):

Índice 10 (desde 2011):

Indicadores de calidad de la revista:

Categoría ANEP:

Puntuación MIAR (2015):

Opinión Expertos (RESH 2009):
$\mathrm{A}+$

9.8

85.46

Porcentajes de rechazos y artículos que comuniquen resultados de investigación originales (véase la Figura 1).

$\rightarrow$ \% Rechazos ־ \% Investigación

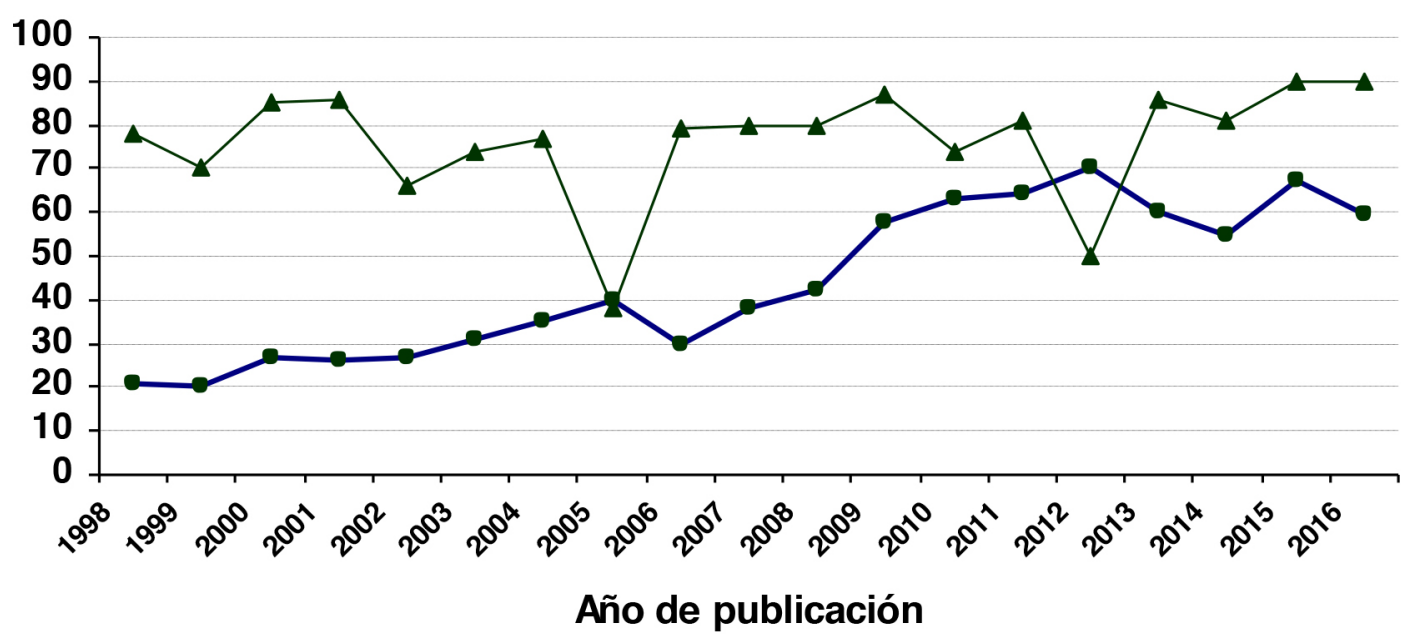

Figura 1. Porcentaje de manuscritos rechazados (rechazos) y artículos de investigación originales (investigación), correspondientes a la Revista de Psicopatología y Psicología Clínica desde 1998 hasta el momento actual. 